\title{
PENGARUH EKSTRAK KULIT JENGKOL DAN UMBI GADUNG RACUN TERHADAP MORTALITAS KEONG MAS (Pomacea canaliculata Lamarck)
}

(The Effect of Jengkol Peel and Poison Yam Tuber Extract on the Mortality of The Golden Snail (Pomacea canaliculata Lamarck)

\author{
Mohammad Ikhsan ${ }^{1}$, Husni Husni ${ }^{1 *}$, Alfian Rusdy ${ }^{1}$ \\ ${ }^{1}$ Program Studi Proteksi Tanaman, Fakultas Pertanian, Universitas Syiah Kuala \\ *Corresponding author: husnimusannif@unsyiah.ac.id
}

\begin{abstract}
Abstrak: Hasil penelitian menunjukkan bahwa kombinasi aplikasi ekstrak kulit jengkol dan ekstrak umbi gadung racun berpengaruh terhadap penghambatan makan, waktu kematian dan mortalitas keong mas. Persentase penghambatan makan tertinggi terdapat pada perlakuan $\mathrm{J}_{3} \mathrm{G}_{3}$ rata-rata $3,77 \%$. Aktifitas makan keong mas mengalami penghambatan karena peran senyawa alkaloid pada ekstrak kulit jengkol yang bersifat racun perut bersinergi dengan senyawa HCN yang membuat metabolisme keong mas terganggu. Waktu kematian tertinggi terdapat pada perlakuan J3G3 dengan jumlah kematian 10 ekor. Kecepatan kematian keong mas sangat ditentukan oleh tingginya kandungan senyawa toksik yang terdapat pada berbagai perlakuan konsentrasi ekstrak kulit jengkol dan umbi gadung racun, dimana semakin tinggi kandungan senyawa toksik yang terdapat pada ekstrak kulit jengkol dan umbi gadung racun maka kematian keong mas akan semakin cepat. Mortalitas keong mas tertinggi terdapat pada perlakuan $\mathrm{J}_{3} \mathrm{G}_{3}$ yang mencapai $100 \%$. Tingginya mortalitas keong mas dipengaruhi oleh senyawa toksik yang terdapat pada ekstrak kulit jengkol yaitu alkaloid, steroid/triterpenoid, saponin, flavanoid dan tanin bersinergi dengan senyawa toksik yang terdapat pada umbi gadung racun yaitu dioskorin dan asam sianida.
\end{abstract}

Kata kunci: Mortalitas, Keong mas, Jengkol, Umbi gadung racun

\begin{abstract}
The results showed that the combination of jengkol peel extract and poison yam tuber had an effect on feeding inhibition, time of death and mortality of golden snails. The highest percentage of food inhibition was found in the J3G3 treatment, an average of $3.77 \%$. The activity of eating golden snails was hampered because of the role of alkaloid compounds in jengkol skin extract which is a stomach poison in synergy with $\mathrm{HCN}$ compounds that interfere with the metabolism of golden snails. The highest time of death was found in the J3G3 treatment with 10 deaths. The speed of death of golden snails is largely determined by the high content of toxic compounds found in various concentrations of extracts of jengkol peel and gadung tubers, where the higher the content of toxic compounds contained in the extracts of jengkol peel and gadung tubers. the faster the death of the golden snail. The highest gold snail mortality was found in the J3G3 treatment which reached $100 \%$. The high mortality of golden snails is influenced by the toxic compounds found in the jengkol peel extract, namely alkaloids, steroids/triterpenoids, saponins, flavonoids and tannins that synergize with toxic compounds found in gadung tubers, namely dioscorin and cyanide acid.
\end{abstract}

Keywords: Mortality, Golden Snail, Jengkol, Poison Yam Tuber

\section{PENDAHULUAN}

Keong mas adalah salah satu hama utama yang menyerang tanaman padi, keong mas menyerang mulai pada masa pembibitan sampai tanaman padi memasuki fase generatif. Keong mas menyerang dengan memakan daun dan pangkal batang tanaman padi yang masih muda. Keong mas menjadi hama penting yang menyerang tanaman padi terutama di areal persawahan irigasi. Serangan yang cukup berat terjadi mulai pada saat persemaian hingga tanaman padi berumur 4 minggu setelah tanam (Musman, 2010).

Pengendalian keong mas telah banyak dilakukan diantaranya dengan menggunakan metode mekanis dan pestisida sintetis. Akan tetapi, cara 
pengendalian dengan menggunakan pestisida sintetis dapat menimbulkan pencemaran lingkungan (Isnaningsih et al., 2011). Untuk meminimalisir dampak pencemaran lingkungan akibat pestisida sintetis perlu adanya alternatif untuk mengendalikan hama keong mas yaitu dengan menggunakan pestisida nabati. Pestisida nabati adalah pestisida yang berasal dari tumbuhan yang dapat dimanfaatkan untuk mengendalikan hama sehingga dapat mengurangi pengaruh negatif terhadap lingkungan yang ditimbulkan oleh pestisida sintetis (Sudarmo, 2005). Salah satu bahan baku yang dapat digunakan sebagai pestisida nabati untuk mengendalikan keong mas adalah kulit jengkol dan umbi gadung racun.

Jengkol (Pithecellobium lobatum) merupakan tanaman yang berasal Asia Tenggara, di Indonesia tanaman ini dikenal dengan tanaman jengkol. Bagian dari tanaman jengkol mengandung senyawa-senyawa yang dapat didimanfaatkan sebagai pestisida nabati (Mawardi et al., 2018). Menurut Ambarningrum et al. (2012) Kulit buah jengkol yang dapat dimanfaatkan sebagai persisida nabati adalah asam jengkolat, selain itu kulit jengkol juga mengandung unsur sulfur yang bersifat racun. Juwita et al. (2014) menyatakan bahwa kulit jengkol bersifat racun dengan mampu mematikan larva Culex sp. sebesar 73,3\% pada LC 73.3 dengan konsentrasi $0.5 \%$.

Gadung racun (Discorea hispida Dennst.) adalah tanaman umbi-umbian yang mengandung senyawa-senyawa toksik berbahaya. Umbi gadung racun mengandung dioskorin yang bersifat toksik (Kardinan, 2011). Umbi gadung racun juga mengandung diosgenin yang apabila dikonsumsi dengan pengolahan yang kurang tepat akan mengakibatkan keracunan (Santoso et al., 2015). Bagian tanaman gadung racun yang dimanfaatkan sebagai pestisida nabati adalah umbi gadung racun. Umbi gadung racun mengandung asam sianida yang juga bersifat racun, senyawa ini dapat menghambat pernapasan dan perkembangan sel yang tidak sempurna bagi semua mahkluk hidup (Pambayun et al., 2007). Boesri \& Priyanto. (2017) mengatakan bahwa aplikasi ekstrak umbi gadung racun dengan pelarut etanol 70\% konsentrasi $1 \mathrm{cc} / \mathrm{l}$ dapat mematikan siput murbei $40 \%$ selama 24 jam setelah aplikasi.

Pengendalian keong mas banyak dilakukan dengan menggunakan salah satu bahan pestisida di atas yaitu kulit jengkol atau umbi gadung racun, tetapi belum ada penelitian yang menggabungkan dua pestisida di atas dalam satu aplikasi. Oleh karena itu penulis tertarik untuk melakukan penelitian dengan menggabungkan dua bahan sekaligus yaitu kulit jengkol dan umbi gadung racun dalam satu aplikasi.

\section{METODE PENELITIAN}

\section{Tempat dan Waktu Penelitian}

Penelitian ini dilakukan di Laboratorium Kimia FKIP USK dan Komplek Perumahan Lam Ujong Indah Desa Labuy, Kecamatan Baitussalam, Kabupaten Aceh Besar Pada bulan Juni sampai dengan Oktober 2020. 


\section{Rancangan Penelitian}

Penelitian ini menggunakan Rancangan Acak Lengkap (RAL) faktorial 3 x 3 dengan 3 ulangan dan 2 faktor. Dengan demikian diperoleh 9 kombinasi perlakuan dengan 3 ulangan sehingga diperoleh 27 unit percobaan.

\section{Prosedur Penelitian:}

Penyediaan keong mas

Keong mas disediakan dengan mengumpulkan telur keong mas dari areal persawahan, selanjutnya setelah menetas, keong mas dipelihara hingga dewasa sampai umur 2,5 bulan. Keong mas yang sudah dewasa dikumpulkan lalu dimasukkan kedalam wadah kemudian dipersiapkan untuk penelitian sesuai perlakuan.

Pembuatan pestisida nabati ekstrak kulit jengkol dan umbi gadung racun

Ekstrak kulit jengkol dan umbi gadung racun yang digunakan adalah ekstrak dalam bentuk cair. Kulit jengkol dan umbi gadung racun yang telah dibersihkan kemudian dikeringkan. Sebanyak 1000 gram kulit jengkol dan umbi gadung racun dimasukkan ke dalam sebuah wadah lalu dimaserasi dengan alkohol $70 \%$ sebanyak 1 liter, selanjutnya diaduk sesekali selama 6 jam, lalu diendapkan selama 24 jam dan hasil maserasi pertama ditampung lalu diulangi dua kali untuk mendapat hasil ekstrak $100 \%$ maserat yang dipekatkan dengan alat rotary evaporator (IKA RV 10 Basic) pada suhu $50^{\circ} \mathrm{C}$ dan $50 \mathrm{rpm}$.

\section{Aplikasi ekstrak pestisida nabati pada keong mas}

Masing-masing plot yang telah diberi air sebanyak 2 liter dimasukkan 10 ekor keong mas yang telah diberi tanda 1 sampai 10 , selanjutnya semua plot dimasukkan ekstrak kulit jengkol dan umbi gadung racun sesuai dengan perlakuan masing-masing. Setelah itu 50 gram tanaman padi muda sebagai pakan keong mas dimasukkan ke dalam masing-masing plot.

\section{Parameter Pengamatan:}

Persentase penghambatan makan keong mas

Pengamatan penghambat makan keong mas dilakukan pada 2, 4, 6 dan 8 hari setelah aplikasi, pengamatan dilakukan dengan menimbang berat kering awal pakan dan berat kering akhir pakan dengan menggunakan neraca digital (Uniweigh), pergantian pakan dilakukan setiap dua hari sekali, persentase penghambatan makan dihitung dengan menggunakan rumus Prijono (2002) yaitu:

Keterangan :

$$
\mathrm{PM}=\frac{\mathrm{Bk}-\mathrm{Bp}}{\mathrm{Bk}+\mathrm{Bp}} \times 100 \%
$$

$\mathrm{PM}=$ Persentase Penghambat makan

$\mathrm{Bk}=$ Berat awal pada perlakuan

$\mathrm{Bp}=$ Berat akhir pada perlakuan 


\section{Rata-rata Kecepatan Waktu Kematian Keong Mas}

Kecepatan kematian dihitung setiap hari setelah aplikasi sampai ada unit perlakuan yang mati $100 \%$. Rata-rata kecepatan waktu kematian dihitung dengan menggunakan rumus sebagai berikut:

$$
\text { Kecepatan Waktu Kematian }=\frac{\text { Waktu pengamatan } \mathrm{x} \text { Jumlah yang mati }}{\text { Jumlah keong mas awal }}
$$

\section{Mortalitas keong mas}

Pengamatan mortalitas keong mas dilakukan setiap hari dengan menghitung jumlah keong mas yang mati akibat perlakuan. Mortalitas keong mas dihitung dengan menggunakan rumus Prijono (2002) yaitu:

$$
\mathrm{M}=\frac{r}{n} \times 100 \%
$$

Keterangan :

$\mathrm{M}=$ Mortalitas keong mas

$\mathrm{r}=$ Jumlah keong mas yang mati

$\mathrm{n}=$ Jumlah keong mas keseluruhan

\section{HASIL DAN PEMBAHASAN}

\section{Persentase Penghambatan Makan Keong Mas}

Rata-rata persentase penghambatan makan keong mas akibat adanya interaksi pengaruh konsentrasi ekstrak kulit jengkol dan umbi gadung racun pada pengamatan 2, 4, 6 dan 8 HSA dapat dilihat pada table 1 berikut:

Tabel 1. Penghambatan makan keong mas akibat perlakuan berbagai konsentrasi

\begin{tabular}{|c|c|c|c|c|}
\hline \multirow[t]{2}{*}{ Hari Pengamatan } & \multicolumn{4}{|c|}{$\begin{array}{c}\text { Interaksi Antara Konsentrasi Ekstrak Kulit Jengkol dan } \\
\text { Umbi Gadung Racun }\end{array}$} \\
\hline & $\mathrm{J}_{\mathrm{J}}^{\mathrm{G}}$ & $\mathrm{G}_{1}$ & $\mathrm{G}_{2}$ & $\mathrm{G}_{3}$ \\
\hline 2 HAS & $\mathbf{J}_{1}$ & $\begin{array}{c}0,91 \mathrm{bA} \\
(0,00)\end{array}$ & $\begin{array}{c}0,68 \mathrm{aA} \\
(0,01)\end{array}$ & $\begin{array}{c}0,02 \mathrm{aA} \\
(0,87)\end{array}$ \\
\hline $\mathrm{BNT}=0,280$ & $\begin{array}{l}\mathrm{J}_{2} \\
\mathrm{~J}_{3}\end{array}$ & $\begin{array}{c}0,00 \mathrm{abA} \\
(0,79) \\
0,01 \mathrm{aA} \\
(0,57)\end{array}$ & $\begin{array}{c}0,01 \mathrm{aA} \\
(0,68) \\
0,01 \mathrm{aA} \\
(0,65)\end{array}$ & $\begin{array}{c}0,04 \mathrm{ab} \\
(1,14) \\
0,04 \mathrm{bB} \\
(1,19)\end{array}$ \\
\hline 4 HAS & $\mathrm{J}_{1}$ & $\begin{array}{l}0,01 \mathrm{bA} \\
(0,68) \\
0,17 \mathrm{abA}\end{array}$ & $\begin{array}{c}0,06 \mathrm{aA} \\
(1,40) \\
019 \mathrm{aA}\end{array}$ & $\begin{array}{c}0,31 \mathrm{aA} \\
(3,17) \\
032 \mathrm{abB}\end{array}$ \\
\hline $\mathrm{BNT}=0,142$ & $\mathrm{~J}_{2}$ & $\begin{array}{c}0,17 \mathrm{abA} \\
(2,34) \\
0,34 \mathrm{aA} \\
(3,34)\end{array}$ & $\begin{array}{c}0,19 \mathrm{aA} \\
(2,52) \\
0,35 \mathrm{bA} \\
(3,38)\end{array}$ & $\begin{array}{c}0,32 \mathrm{abB} \\
(3,26) \\
0,35 \mathrm{aA} \\
(3,41)\end{array}$ \\
\hline
\end{tabular}
ekstrak kulit jengkol dan umbi gadung racun (\%) 


\begin{tabular}{ccccc}
\hline \multirow{2}{*}{$6 \mathrm{HAS}$} & & $0,22 \mathrm{aC}$ & $0,24 \mathrm{aB}$ & $0,34 \mathrm{aA}$ \\
& $\mathrm{J}_{1}$ & $(2,67)$ & $(2,81)$ & $(3,36)$ \\
$\mathrm{BNT}=0,051$ & & $0,24 \mathrm{bC}$ & $0,30 \mathrm{bB}$ & $0,36 \mathrm{bA}$ \\
& $\mathrm{J}_{2}$ & $(2,79)$ & $(3,16)$ & $(3,44)$ \\
& & $0,33 \mathrm{cC}$ & $0,36 \mathrm{bA}$ & $0,38 \mathrm{cB}$ \\
\multirow{2}{*}{$8 \mathrm{HAS}$} & $\mathrm{J}_{3}$ & $(3,31)$ & $(3,44)$ & $(3,52)$ \\
& & $0,28 \mathrm{cC}$ & $0,31 \mathrm{cB}$ & $0,40 \mathrm{cA}$ \\
$\mathrm{BNT}=0,049$ & $\mathrm{~J}_{1}$ & $(3,05)$ & $(3,21)$ & $(3,64)$ \\
& & $0,35 \mathrm{bC}$ & $0,38 \mathrm{bB}$ & $0,41 \mathrm{aB}$ \\
& $\mathrm{J}_{2}$ & $(3,41)$ & $(3,53)$ & $(3,69)$ \\
& & $0,40 \mathrm{aC}$ & $0,42 \mathrm{bB}$ & $0,43 \mathrm{Aa}$ \\
& $\mathrm{J}_{3}$ & $(3,61)$ & $(3,72)$ & $(3,77)$ \\
\hline
\end{tabular}

Keterangan: Angka-angka yang diikuti oleh huruf yang sama pada kolom dan baris yang sama tidak berbeda nyata pada taraf 5\% (Uji BNT 0,05), huruf kecil pembanding vertikal dan huruf besar pembanding horizontal, ( ) = data setelah ditransformasi dengan Arc $\sin \sqrt{\mathrm{X}}$

Hasil uji $\mathrm{F}$ menunjukkan bahwa ekstrak kulit jengkol dan umbi gadung racun berpengaruh nyata terhadap penghambat makan keong mas pada pengamatan 2, 4, 6 dan 8 HSA. Penghambatan makan tertinggi terdapat pada perlakuan $\mathrm{J}_{3} \mathrm{G}_{3}(6 \mathrm{ml}$ ekstrak kulit jengkol $+5 \mathrm{ml}$ ekstrak umbi gadung racun $)$ dengan rata-rata $3,77 \%$.

Setelah aplikasi ekstrak kulit jengkol dan umbi gadung racun terjadi perubahan tingkah laku pada keong mas yaitu pergerakan keong mas yang awalnya sangat aktif berubah jadi lambat, aktifitas makan keong mas yang awalnya tinggi juga berubah menjadi rendah.

Aktifitas makan keong mas mengalami penurunan akibat senyawa tanin dan saponin pada kulit jengkol yang bersifat antifeedant, senyawa yang paling berpengaruh pada kulit jengkol yaitu alkaloid bekerja sebagai racun perut, sehingga mengakibatkan proses metabolisme berlangsung lebih lama (Astuti, 2013). Selain itu, senyawa asam sianida (HCN) yang terkandung pada umbi gadung juga membuat metabolisme keong mas terganggu sehingga proses absorbsi makanan menjadi terhambat (Telaumbanua, 2017).

Sesuai dengan pendapat Anggraini \& Dyah (2009) bahwa senyawa tanin, terpenoid dan alkaloid dapat mempengaruhi keseimbangan hormon saraf dan otot serta mampu menghambat aktifitas makan keong mas. Matsushita et al. (2002) juga menambahkan bahwa senyawa tanin yang terdapat pada kulit jengkol mampu menolak nutrisi dan menghambat kerja enzim sehingga hindrolisis pati menjadi rendah, akibatnya lama-kelamaan akan terjadi kematian pada keong mas.

Hasil penelitian Astuti (2013) menunjukkan bahwa ekstrak kulit jengkol masuk ke dalam tubuh keong mas melalui air dan makanan yang dikonsumsi. Racun akan masuk ke daerah usus tengah di mana daerah tersebut merupakan tempat terjadinya penyerapan makanan. Makanan akan masuk ke jaringan epithelium untuk kemudian diolah dan hasilnya diedarkan ke seluruh tubuh oleh hemolimfe. Mekanisme penghambatan makan keong mas terjadi akibat jaringan epithelium yang terdapat pada usus tengah mengalami kerusakan akibat senyawa toksik pada yang terdapat pada ekstrak kulit jengkol, dimana jaringan ini berfungsi untuk menyerap makanan. 
Senyawa-senyawa toksik yang terdapat pada ekstrak kulit jengkol dan umbi gadung racun bekerja secara sinergis dalam menurunkan aktivitas makan keong mas. Akibat adanya senyawa dari kedua ekstrak tersebut sistem pencernaan keong mas menjadi rusak, sehingga aktivitas makan keong mas terhambat.

\section{Rata-rata Waktu Kematian Keong Mas}

Rata-rata waktu kematian keong mas akibat pemberian ekstrak kulit jengkol dan umbi gadung racun dapat dilihat pada table 2 berikut:

Tabel 2. Rata-rata waktu kematian keong mas akibat perlakuan berbagai konsentrasi ekstrak kulit jengkol dan umbi gadung racun

\begin{tabular}{cccc}
\hline Perlakuan & $\mathrm{G}_{1}$ & $\mathrm{G}_{2}$ & $\mathrm{G}_{3}$ \\
\hline $\mathrm{J}_{1}$ & $7,00 \mathrm{aA}$ & $7,00 \mathrm{aA}$ & $7,33 \mathrm{aA}$ \\
& $(2.64)$ & $(2,64)$ & $(2,71)$ \\
$\mathrm{J}_{2}$ & $7,67 \mathrm{aA}$ & $9,33 \mathrm{bB}$ & $10,00 \mathrm{bB}$ \\
& $(2,77)$ & $(3,05)$ & $(3,16)$ \\
$\mathrm{J}_{3}$ & $10,00 \mathrm{bA}$ & $10,00 \mathrm{bA}$ & $10,00 \mathrm{bA}$ \\
& $(3,16)$ & $(3,16)$ & $(3,16)$ \\
\hline BNT $_{0,05}$ & & 0,183 & \\
\hline
\end{tabular}

Keterangan: Angka-angka yang diikuti oleh huruf yang sama pada kolom dan baris yang sama tidak berbeda nyata pada taraf 5\% (Uji BNT 0,05), huruf kecil pembanding vertikal dan huruf besar pembanding horizontal, $(\quad)=$ data setelah ditransformasi dengan $\sqrt{\mathrm{X}}$

Hasil uji F menunjukkan bahwa ekstak kulit jengkol dan umbi gadung racun berpengaruh nyata terhadap waktu kematian keong mas, dengan waktu kematian tercepat terdapat pada perlakuan $\mathrm{J}_{3} \mathrm{G}_{3}(6 \mathrm{ml}$ ekstrak kulit jengkol $+5 \mathrm{ml}$ ekstrak umbi gadung racun) dengan rata-rata 10 ekor.

Kematian keong mas diakibatkan karena tempat hidupnya yaitu air sudah tercemar dengan senyawa saponin, alkaloid, flavonoid, tanin dan terpenoid dari kulit jengkol. Alkaloid merupakan senyawa toksik yang dapat menurunkan aktifitas makan keong mas. Keong mas mengalami keracunan akibat senyawa alkaloid yang mengakibatkan terganggunya sistem metabolisme (Astuti, 2013). Selanjutnya Ferinda et al. (2018) menyatakan bahawa senyawa asam sianida yang terdapat pada ekstrak umbi gadung racun dapat menghambat proses pernapasan dan perkembangan sel. Sedangkan asam jengkolat yang terdapat di dalam ekstrak kulit jengkol dapat mengganggu absorbsi makanan karena kerusakan jaringan ephitelium pada usus tengah. Kegagalan absorbsi tersebut mengakibatkan malnutrisi sehingga akhirnya terjadi kematian pada keong mas (Astuti, 2013).

Menurut Putra \& Zein (2016) faktor penentu dalam mempercepat kematian keong mas adalah semakin tingginya ekstrak yang digunakan maka akan semakin cepat waktu kematian dan semakin banyak senyawa toksik yang masuk ke dalam tubuh keong mas maka jaringan yang dirusak akan semakin banyak sehingga akan menyebabkan kematian. 


\section{Mortalitas Keong Mas}

Pengaruh pemberian ekstrak kulit jengkol tehadap mortalitas keong mas

Hasil uji $\mathrm{F}$ menunjukkan bahwa terdapat pengaruh yang nyata pada pengamatan 2, 3, 4 dan 5 HSA terhadap mortalitas keong mas, sedangkan pada 6 dan 7 HSA terdapat interaksi antara kulit jengkol atau umbi gadung racun.

Rata-rata mortalitas keong mas akibat pemberian ekstrak kulit jengkol dapat dilihat pada Tabel 3 berikut:

Tabel 3. Mortalitas keong mas akibat perlakuan berbagai konsentrasi ekstrak kulit jengkol (\%)

\begin{tabular}{ccccc}
\hline Perlakuan & 2 HSA & 3 HSA & 4 HAS & 5 HAS \\
\hline $\mathrm{J}_{1}$ & $2,22 \mathrm{a}$ & $5,56 \mathrm{a}$ & $11,11 \mathrm{a}$ & $20,00 \mathrm{a}$ \\
& $(4,80)$ & $(10,64)$ & $(16,20)$ & $(26,24)$ \\
$\mathrm{J}_{2}$ & $7,78 \mathrm{~b}$ & $14,44 \mathrm{~b}$ & $22,22 \mathrm{~b}$ & $30,00 \mathrm{~b}$ \\
& $(12,45)$ & $(20,84)$ & $(27,71)$ & $(35,50)$ \\
$\mathrm{J}_{3}$ & $10,00 \mathrm{~b}$ & $17,78 \mathrm{a}$ & $32,32 \mathrm{~b}$ & $42,22 \mathrm{c}$ \\
& $(16,34)$ & $(23,22)$ & $(33,98)$ & $(40,23)$ \\
\hline BNT $_{0,05}$ & 6,948 & 8,471 & 8,962 & 5,901 \\
\hline
\end{tabular}

Keterangan: Angka-angka yang diikuti oleh huruf yang sama pada kolom dan baris yang sama tidak berbeda nyata pada taraf $5 \%$ (Uji BNT 0,05), ( ) = data setelah ditransformasi dengan Arc $\sin \sqrt{X}$

Hasil penelitian menunjukkan bahwa ekstrak kulit jengkol berpengaruh nyata terhadap mortalitas keong mas pada 2, 3, 4 dan 5 HSA. Mortalitas tertinggi terdapat pada perlakuan $\mathbf{J}_{3}(6 \mathrm{ml}$ ekstrak kulit jengkol) pada pengamatan 5 HSA dengan rata-rata $42,22 \%$, sedangkan mortalitas terendah terdapat pada perlakuan $\mathrm{J} 1$ ( $2 \mathrm{ml}$ ekstrak kulit jengkol) pada pengamatan 2 HSA dengan rata-rata 2,22\%.

Mortalitas keong mas akibat aplikasi ekstrak kulit jengkol terus mengalami kenaikan yang signifikan pada setiap harinya. Hasil penelitian Astuti (2013) menunjukkan bahwa kandungan senyawa toksik yang terdapat pada ekstrak kulit jengkol yang terdiri dari saponin, alkaloid, terpenoid, tanin dan falavanoid masuk ke dalam tubuh keong mas mempengaruhi pencernaan sehingga bahan baku hasil pencernaan lambat mencapai organ sasaran. Alkaloid yang terdapat pada ekstrak kulit jengkol menghambat proses enzimatik, hal ini diakibatkan karena protozoa yang terdapat pada saluran usus tengah telah mati akibat senyawa alkaloid. Senyawa ini juga menyebabkan saluran pencernaan menjadi iritasi, sehingga menyebabkan kematian pada keong mas.

\section{Pengaruh pemberian ekstrak umbi gadung racun terhadap mortalitas keong mas}

Hasil uji $\mathrm{F}$ menunjukkan bahwa terdapat pengaruh yang nyata pada pengamatan 2, 3, 4 dan 5 HSA terhadap mortalitas keong mas, sedangkan pada 6 dan 7 HSA terdapat interaksi antara kulit jengkol atau umbi gadung racun.

Rata-rata mortalitas keong mas akibat pemberian ekstrak umbi gadung racun dapat dilihat pada table 4 berikut: 
Tabel 4. Mortalitas keong mas akibat perlakuan berbagai konsentrasi ekstrak umbi gadung racun (\%)

\begin{tabular}{ccccc}
\hline Perlakuan & $2 \mathrm{HAS}$ & $3 \mathrm{HAS}$ & $4 \mathrm{HAS}$ & $5 \mathrm{HAS}$ \\
\hline $\mathrm{G}_{1}$ & $1,11 \mathrm{a}$ & $5,56 \mathrm{a}$ & 13,13 & $18,89 \mathrm{a}$ \\
& $(2,85)$ & $(10,64)$ & $(20,10)$ & $(25,33)$ \\
$\mathrm{G}_{2}$ & $7,78 \mathrm{~b}$ & $14,44 \mathrm{~b}$ & 24,44 & $34,44 \mathrm{~b}$ \\
& $(12,45)$ & $(20,84)$ & $(27,74)$ & $(35,59)$ \\
$\mathrm{G}_{3}$ & $11,11 \mathrm{~b}$ & $17,78 \mathrm{~b}$ & 27,78 & $38,89 \mathrm{~b}$ \\
& $(18,29)$ & $(23,22)$ & $(30,05)$ & $(38,05)$ \\
\hline BNT $_{0,05}$ & 6,948 & 8,471 & - & 5,901 \\
\hline
\end{tabular}

Keterangan: Angka-angka yang diikuti oleh huruf yang sama pada kolom dan baris yang sama tidak berbeda nyata pada taraf $5 \%$ (Uji BNT 0,05), ( ) = data setelah ditransformasi dengan Arc $\sin \sqrt{X}$

Hasil penelitian menunjukkan bahwa ekstrak umbi gadung racun berpengaruh nyata terhadap mortalitas keong mas pada pengamatan 2,3 dan 5 HSA, sedangkan pada pengamatan 4 HSA tidak terdapat pengaruh yang nyata. Mortalitas keong mas tertinggi terdapat pada perlakuan $\mathrm{G}_{3}(5 \mathrm{ml}$ ekstrak umbi gadung racun) dengan rata-rata $38,89 \%$ dan yang terendah terdapat pada perlakuan $\mathrm{G}_{1}(1 \mathrm{ml}$ ekstrak umbi gadung racun) dengan rata-rata $1,11 \%$.

Penelitian Ferinda et al. (2018) menunjukkan bahwa umbi gadung racun mengandung senyawa dioskorin. Senyawa ini jika larut dalam air menyebabkan muntah darah dan sulit bernapas. Pambayun (2007) juga menambahkan bahwa umbi gadung racun megandung asam sianida dan dioskorin, senyawa ini bersifat sangat toksik karena mempengaruhi sistem respirasi pada organisme, yakni mempersempit rongga pernapasan sehingga pasokan $\mathrm{O}_{2}$ sangat berkurang. Sehingga dapat dikatakan bahwa kematian keong mas terjadi karena terpapar senyawa-senyawa toksik yaitu dioskorin dan asam sianida yang terdapat pada umbi gadung racun.

Pengaruh pemberian ekstrak kulit jengkol dan umbi gadung racun terhadap mortalitas keong mas

Hasil uji $\mathrm{F}$ menunjukkan bahwa terdapat pengaruh yang nyata akibat pemberian ekstrak kulit jengkol dan umbi gadung racun terhadap mortalitas keong mas pada pengamatan 6 dan 7 HSA (Lampiran 16, 19).

Rata-rata mortalitas keong mas akibat pemberikan ekstrak kulit jengkol dan umbi gadung racun pada pengamatan 6 dan 7 HSA dapat dilihat pada table 5 berikut: 
Tabel 5. Mortalitas keong mas akibat pemberian ekstrak kulit jengkol dan umbi gadung racun $(\%)$

\begin{tabular}{|c|c|c|c|c|}
\hline \multirow[t]{2}{*}{ Hari Pengamatan } & \multicolumn{4}{|c|}{$\begin{array}{c}\text { Interaksi Antara Ekstrak Kulit Jengkol dan Umbi } \\
\text { Gadung Racun }\end{array}$} \\
\hline & $\mathrm{G}$ & $\mathrm{G}_{1}$ & $\mathrm{G}_{2}$ & $\mathrm{G}_{3}$ \\
\hline $6 \mathrm{HAS}$ & $\mathrm{J}_{1}$ & $\begin{array}{c}23.33 \mathrm{aA} \\
(28,78)\end{array}$ & $\begin{array}{c}26,67 \mathrm{aA} \\
(31,00)\end{array}$ & $\begin{array}{c}26,67 \mathrm{aA} \\
(31,00)\end{array}$ \\
\hline \multirow[t]{3}{*}{$\mathrm{BNT}=9,832$} & \multirow[t]{2}{*}{$\mathrm{J} 2$} & $\begin{array}{c}20,00 \mathrm{aA} \\
(26,07)\end{array}$ & $\begin{array}{c}46,67 \mathrm{bB} \\
(43,08)\end{array}$ & $\begin{array}{c}50,00 \mathrm{Bb} \\
(45,00)\end{array}$ \\
\hline & & $30,00 \mathrm{aA}$ & $56,67 \mathrm{bB}$ & $76,67 \mathrm{cC}$ \\
\hline & $\mathrm{J}_{3}$ & $(33,21)$ & $(48,93)$ & $(61,71)$ \\
\hline \multirow{2}{*}{7 HAS } & \multirow[t]{2}{*}{$\mathrm{J}_{1}$} & $\begin{array}{c}53,33 \mathrm{aA} \\
(46,92)\end{array}$ & $\begin{array}{c}56,67 \mathrm{aA} \\
(48,93)\end{array}$ & $\begin{array}{c}63,33 \mathrm{aA} \\
(52,78)\end{array}$ \\
\hline & & $60,00 \mathrm{aA}$ & $73,33 \mathrm{aA}$ & $96,67 \mathrm{bB}$ \\
\hline \multirow[t]{3}{*}{$\mathrm{BNT}=10,972$} & \multirow[t]{2}{*}{$\mathrm{J}_{2}$} & $(50,85)$ & $(59,00)$ & $(83,25)$ \\
\hline & & $56,67 \mathrm{aA}$ & $86,67 \mathrm{bB}$ & $100,00 \mathrm{bC}$ \\
\hline & $\mathrm{J}_{3}$ & $(48,85)$ & $(83,25)$ & $(89,09)$ \\
\hline
\end{tabular}

Keterangan: Angka-angka yang diikuti oleh huruf yang sama pada kolom dan baris yang sama tidak berbeda nyata pada taraf 5\% (Uji BNT 0,05), huruf kecil pembanding vertikal dan huruf besar pembanding horizontal, ( ) = data setelah ditransformasi dengan Arc $\sin \sqrt{\mathrm{X}}$

Hasil penelitian menunjukkan bahwa ekstak kulit jengkol dan umbi gadung racun berpengaruh nyata terhadap mortalitas keong mas pada pengamatan 6 dan 7 HSA. Mortalitas tertinggi terdapat pada perlakuan $\mathrm{J}_{3} \mathrm{G}_{3}(6 \mathrm{ml}$ ekstrak kulit jengkol $+5 \mathrm{ml}$ ekstrak umbi gadung racun) dengan rata-rata mortalitas $100 \%$ (Tabel 5).

Senyawa toksik pada ekstrak kulit jengkol bersinergi dengan senyawa toksik yang terdapat pada umbi gadung racun karena masing-masing ekstrak mempunyai senyawa toksik yang bekerja saling tindak yang menyebabkan kematian pada keong mas. Astuti (2013) menyatakan bahwa senyawa alkaloid yang terdapat pada ekstrak kulit jengkol mempengaruhi sistem pencernaan sehingga bahan baku hasil pencernaan lambat mencapai organ sasaran. Selanjutnya Ferinda et al. (2018) menyatakan bahwa umbi gadung racun mengandung dioskorin yang jika larut dalam air dan dapat menyebabkan sulit bernafas hingga kematian.

Ekstrak kulit jengkol dan umbi gadung racun berpengaruh nyata dalam mematikan keong mas. Ekstrak tersebut mampu mematikan keong mas dengan terhambatnya proses pernapasan keong mas, hal ini ditandai dengan tubuh keong mas yang terus-menerus mengeluarkan lendir lalu lama-kelamaan mengalami kematian dan tubuh keluar dari cangkang. Hal ini juga sesuai dengan hasil penelitian Musman et al. (2012) yang menunjukkan bahwa jika keong mas mengalami keracunan akibat senyawa toksik maka tubuh keong mas akan terusmenerus mengeluarkan lendir, hal ini dilakukan untuk menetralisir racun dari tubuh, berlebihnya produksi lendir oleh keong mas akan menutup saluran pernapasan, sehingga proses pernapasan menjadi terganggu bahkan dapat terhenti total. Selanjutnya Francis et al. (2002) juga menyatakan bahwa proses pernapasan 
keong mas yang terhambat diakibatkan karena perjalanan oksigen melalui insang terhalang oleh lendir-lendir pada tubuh keong mas.

Semakin lama waktu pemberian ekstrak maka mortalitas yang terjadi akan semakin tinggi. Semakin banyak senyawa toksik yang masuk ke dalam tubuh keong mas maka jaringan yang dirusak akan semakin banyak sehingga lamakelamaan keong mas akan mati. Keong mas yang diaplikasikan senyawa toksik dari ekstrak kulit jengkol dan umbi gadung racun akan mengakibatkan nafsu makan berkurang, pergerakan jadi tidak terlalu aktif, lendir keluar dari tubuh secara berlebihan, keluarnya tubuh dari cangkang dan mati (Laoh et al., 2013).

\section{KESIMPULAN}

Ekstrak kulit jengkol dan umbi gadung racun dapat dimanfaatkan sebagai pestisida nabati untuk mengendalikan keong mas (Pomacea canaliculata) karena mengandung senyawa-senyawa kimia yang dapat menyebabkan penghambatan makan dan kematian pada keong mas. Aplikasi pestisida botani yang paling efektif dalam mengendalikan keong mas adalah pada kombinasi perlakuan $\mathrm{J}_{3} \mathrm{G}_{3}(6$ $\mathrm{ml}$ ekstrak kulit jengkol $+5 \mathrm{ml}$ ekstrak umbi gadung racun) dengan rata-rata kematian keong mas $100 \%$.

\section{DAFTAR PUSTAKA}

Ambarningrum, T. Arthad, B. Pratiknyo, H. \& Priyanto, S. 2012. Ekstrak Kulit Jengkol (Pithecellobium lobatum): Pengaruhnya Sebagai Anti Makan dan Terhadap Efisiensi Pemanfaatan Makanan Larva Instar V Heliothis armigera. Jurnal Sains MIPA Universitas Lampung, 13(3), 155-170.

Anggraini \& Dyah, O. 2009. Uji Efektivitas Ekstrak Mahkota Dewa (Phaleria papuena Warb.) Terhadap Mortalitas Ulat Daun Kubis (Plutella xylostella L.) pada Tanaman Caisin. Skripsi S1. Fakultas Pertanian Universitas Sebelas Maret. Surakarta. 50 hal.

Astuti, P. 2013. Uji Efektivitas Kulit Buah Jengkol (Pithecolobium lobatum) Terhadap Kematian Siput Murbei (Pomacea canaliculata). Ziraa'ah Majalah Ilmiah Pertanian. 37(2), 40-45.

Boesri, H. \& Priyanto, H. 2017. Potensi Umbi Gadung (Dioscorea hispida) dan Daun Zodia (Euodia suaveolens) sebagai Insektisida Nabati. Media Penelitian dan Pengembangan Kesehatan, 27(1), 49-56.

Ferinda, M. Solikhin, S. Indriyati, I. \& Susilo, F. X. 2018. Daya Racun Ekstrak Umbi Gadung (Discorea hispida Dennst) Terhadap Hama Keong Mas (Pomacea sp.) dan Ikan Lele (Clarias sp.) di Rumah Kaca. Jurnal Agrotek Tropika. 6(3).

Francis, G. Keren, Z. Makkar, H. P. S. \& Becker. 2002. The Biological Action of Saponins in Animal Systems: A Review. British Journal of Nutrition. 88:587-605. 
Isnaningsih, Rohmatin, N. \& Marwoto, M. 2011. Keong Hama Pomacea di Indonesia: Karakter Morfologi dan Sebarannya (Mollusca, Gastropoda: Ampullariidae). Berita Biologi. 4 (11), 441-447.

Juwita, E. \& Mahatma, R. 2014. Mortalitas dan Pertumbuhan Larva Nyamuk Culex Sp. Akibat Pemberian Ekstrak Kulit Jengkol (Archidendron pauciflorum Benth.). Jurnal Universitas Riau. 16(3), 185-174.

Kardinan, A. 2011. Penggunaan Pestisida Nabati Sebagai Kearifan Lokal dalam Pengendalian Hama Tanaman Menuju Sistem Pertanian Organik. Pengembangan Inovasi Pertanian. 4(4), 262-278.

Laoh, H. Rustam, R. \& Permana R. 2013. Pemberian Beberapa Konsentrasi Tepung Biji Pinang (Areca catechu L.) Lokal Riau untuk Mengendalikan Hama Keong Mas (Pomacea canaliculata L.) pada Tanaman Padi. PEST Tropical Journal. 1 (2), 145- 157.

Matsushita, H. Mio, T. \& Haruko, O. 2002. Porcine Pancreatic $\alpha$-amylase Shows Binding Activity Toward N-linked Oligosaccharides of Glycoproteins. The Journal of Biological Chemistry. 277, 268-287.

Mawardi, M. Elfrida, E. \& Fitri, R. 2018. Pengaruh Ekstrak Kulit Jengkol dan Daun Sri Rejeki Terhadap Mortalitas Keong Mas (Pomacea canaliculata). Jurnal Jeumpa, 5(1), 56-64.

Musman, M. 2010. Tanin Rhizophora mucronata sebagai Moluskisida Keong Mas (Pomacea canaliculata). Bionatura. 12(3), 184-189.

Musman, M. Sofia, F. \& Kurnianda, V. 2012. Selektivitas fraksi Rf $<0,5$ ekstrak etil asetat (EtOAc) biji putat air (Barringtonia racemosa) terhadap keong mas (Pomacea canaliculata) dan ikan lele lokal (Clarias batrachus). DEPIK Jurnal Ilmu-Ilmu Perairan, Pesisir dan Perikanan. $1(2)$.

Pambayun, R. Gardjito, M. Sudarmadji, S. \& Kuswanto, R. 2007. Phenolic Content and Antibacterial Properties of Various Extracts of Gambir (Uncaria gambir Roxb). Indonesian Journal of Pharmacy. 18(3), 141146.

Prijono, D. 2002. Pengujian Keefektifan Campuran Insektisida: Pedoman Bagi Pelaksanaan Pengujian Efikasi Untuk Pendaftaran Pestisida. Jurusan Hama Penyakit Tumbuhan, Fakultas Pertanian. Institut Pertanian Bogor.

Putra, S. \& Zein, S. 2016. Pengaruh Variasi Konsentrasi Ekstrak Serai (Andropogon nardus) Terhadap Mortalitas Hama Keong Mas (Pomacea caniculata L.). Bioedukasi. 7(1), 43-56.

Santoso, B. Pratama, F. Hamzah, B. \& Pambayun, R. 2015. Karakteristik Fisik dan Kimia Pati Ganyong dan Gadung Racun Termodifikasi Metode Ikatan Silang, Agritceh. 35(3), 273-279.

Sudarmo, S. 2005. Teknologi Tepat Guna Pestisida Nabati, Pembuatan dan Pemanfaatannya. Kanisius. Jakarta. 60 hal.

Telaumbanua, Y. 2017. Uji Potensi Sari Pati Gadung racun (Dioscorea hispida) sebagai Bioinsektisida Hama Walang Sangit (Leptocorisa acuta) Tanaman Padi. Skripsi S1 Progam Studi Pendidikan Biologi STKIPPGRI. Lubuklinggau. 54 hal. 